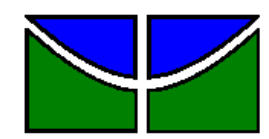

Universidade de Brasília

Faculdade de Economia, Administração e Contabilidade

Departamento de Administração

Curso de Graduação em Administração a distância

SINAIDA MEDEIROS DE ARAUJO

\title{
PRAZER E SOFRIMENTO NO TRABALHO: Relações entre perfil sócio-demográfico e as experiências de prazer e sofrimento no trabalho.
}

Brasília - DF 
SINAIDA MEDEIROS DE ARUAJO

\section{PRAZER E SOFRIMENTO NO TRABALHO: Relações entre perfil sócio-demográfico e as experiências de prazer e sofrimento no trabalho.}

Monografia apresentada a Universidade de Brasília (UnB) como requisito parcial para obtenção do grau de Bacharel em Administração.

Professora supervisora: Profa. Dra. Gisela Demo Fiuza

Professora orientadora: Msc. Rose Mary Gonçalves

Brasília - DF 


\title{
PRAZER E SOFRIMENTO NO TRABALHO: Relações entre perfil sócio-demográfico e as experiências de prazer e sofrimento no trabalho.
}

\begin{abstract}
A Comissão Examinadora, abaixo identificada, aprova o Trabalho de Conclusão do Curso de Administração da Universidade de Brasília da aluna
\end{abstract}

\section{Sinaida Medeiros de Araujo}

\author{
Profa. Dra. Gisela Demo Fiusa \\ Professora Orientadora \\ Msc. Rose Mary Gonçalves \\ Professora Co-orientadora
}


Dedico este simples estudo a todos os trabalhadores, na esperança de estar contribuindo com a construção de uma sociedade em que o trabalho seja um caminho de vida e não de morte. 


\section{AGRADECIMENTOS}

Agradeço a Deus, sobre o qual se alicerça minha fé e força nos momentos de superação, ao apoio sempre presente do meu esposo José Renato, a companhia da minha filha Rafaela Teodora, surpresa feliz que a vida nos trouxe, a Professora Rose Mary, pela tamanha dedicação, disponibilidade, paciência e competência na condução desse trabalho, aos meus respondentes, sem os quais não haveria dados a serem estudados. 
"Com efeito, parece que a exploração do corpo passa sempre e necessariamente por uma neutralização prévia da vida mental, através da organização do trabalho"

Cristophe Dejours. 


\section{RESUMO}

Neste trabalho, procurou-se relacionar as vivências de prazer e sofrimento no trabalho e os perfis socio-demográficos, objetivando responder ao problema de pesquisa: Qual a relação entre perfil pessoal, social e profissional do trabalhador e as experiências de prazer e sofrimento por ele vivenciadas no trabalho? Para responder à pergunta da pesquisa, foram utilizadas as teorias da Psicodinâmica do Trabalho, que fundamentou as definições das variáveis. As vivências de prazersofrimento são definidas em quatro fatores: Gratificação, Liberdade, Insegurança e Desgaste. Os dados demográficos buscam delinear as condições sociais e pessoais do respondente. Participaram da pesquisa 50 trabalhadores, dos quais $60 \%$ são bancários, $82 \%$ residem no DF, $92 \%$ pertencem ao setor de serviços e $62 \%$ trabalham em estatais. Para coleta de dados aplicou-se questionário já validado cientificamente, baseado no Inventário de Valores de Schwartz - IVS. Para análise dos dados, utilizou-se estatística descritiva e correlações. Foi encontrado que os trabalhadores vivenciam prazer e sofrimento de forma moderada, indicando utilização de estratégias defensivas. O fator Insegurança apresentou correlações significativas com as variáveis demográficas Sexo e Renda. Concluiu-se que os fatores de prazer-sofrimento apresentam poucas correlações, o que leva a crer que as vivências de sofrimento não são influenciados pelas características sóciodemográficas do indivíduo, mas sim pela organização do trabalho, considerando-se que esta última influencia o perfil social das pessoas.

Palavras-chave: Psicodinâmica, prazer-sofrimento no trabalho, organização do trabalho. 


\section{SUMÁRIO}

1 INTRODUÇÃO

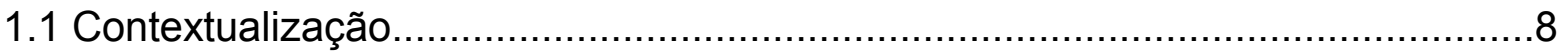

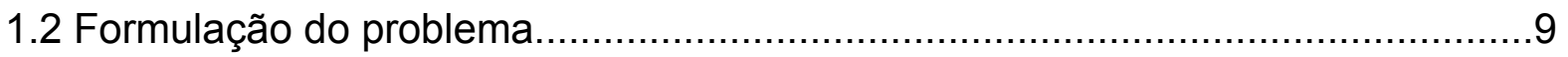

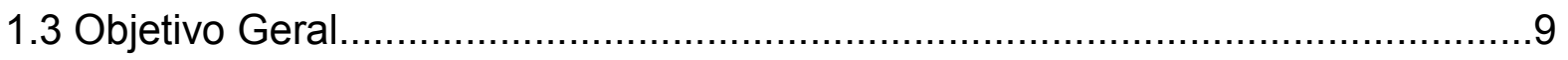

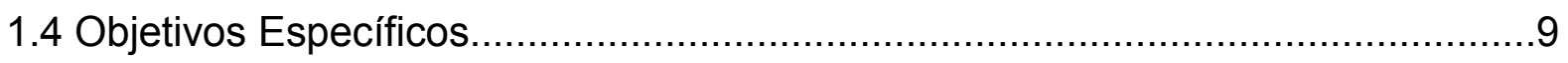

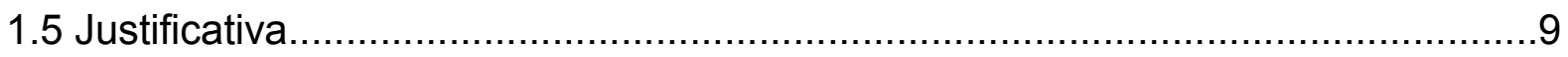

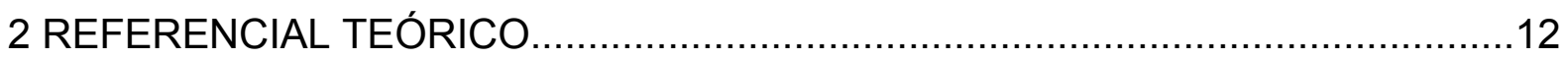

2.1 $\mathrm{O}$ estudo do prazer e do sofrimento no trabalho:Abordagem da psicodinâmica.13

2.2 Algumas origens das experiências de prazer e sofrimento no trabalho: A organização do trabalho, a tarefa, a cultura organizacional, a criação de incompetências, o mecanismo cooperação e reprovação, a injustiça no trabalho....17

$2.3 \mathrm{O}$ trabalhar: da experiência singular à ação coletiva........................................19

2.4 Abordagem quantitativa do constructo prazer-sofrimento.................................21

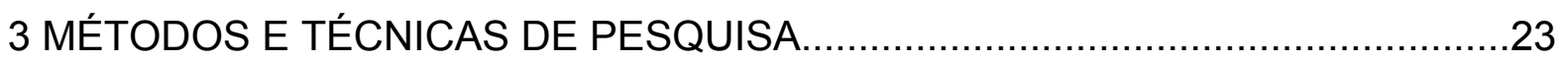

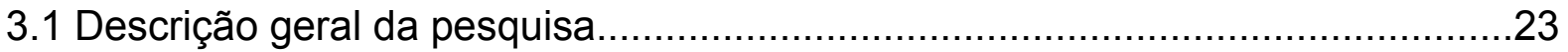

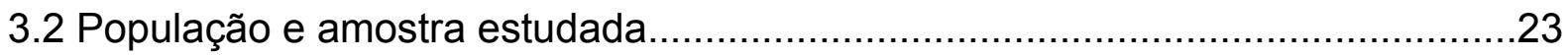

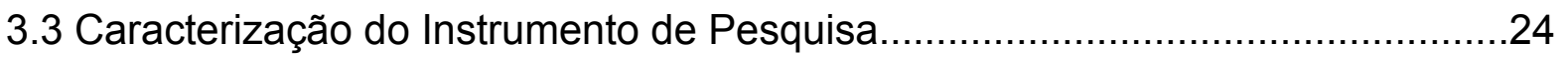

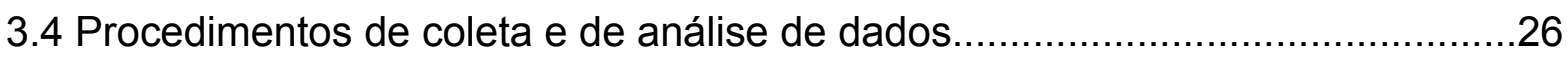

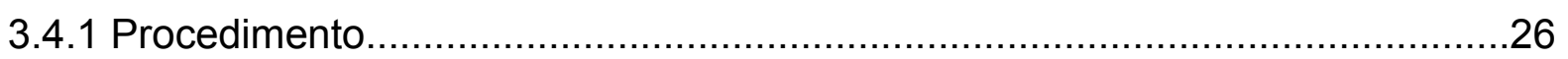

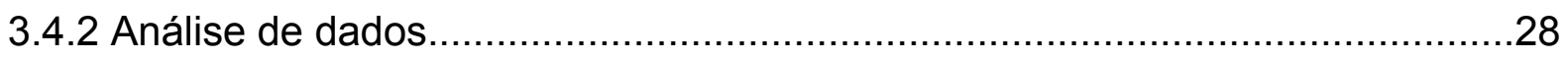

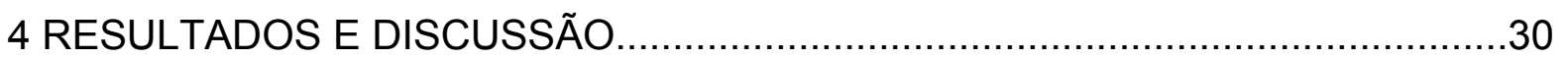

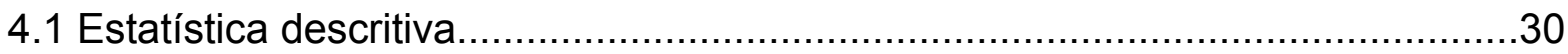

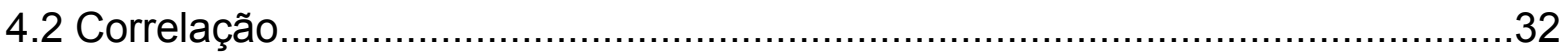

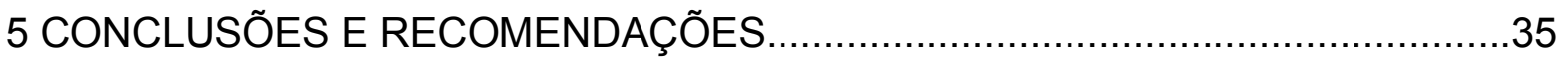

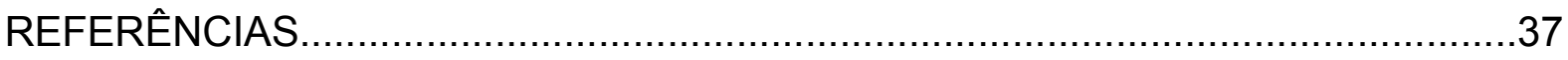

Apêndice A - Instruções para aplicação do questionário.........................................39

Apêndice B - Questionário sobre perfil sócio-demográfico......................................40

Anexo A - Questionário sobre indicadores de prazer e sofrimento no trabalho........42 


\section{INTRODUÇÃO}

\subsection{Contextualização}

O interesse do estudo sobre prazer e sofrimento no trabalho tem crescido nos últimos anos em várias áreas do conhecimento. Em administração, cada vez mais percebe-se o fator humano como principal diferencial nas organizações, em meio a um ambiente de mudanças contínuas e concorrência acirrada. Além disso, trabalhadores insatisfeitos, pouco identificados com suas tarefas e com os objetivos organizacionais, sem relacionamentos interpessoais positivos em seus locais de trabalho e submetidos à desvalorização, ao não reconhecimento de seus esforços tendem a terem seus desempenhos prejudicados, a adoecerem mental e fisicamente e a ausentarem-se dos seus postos de trabalho, aumentando os custos das organizações com problemas de saúde e absenteísmo.

Muitos estudiosos abordam esse tema procurando embasamento teórico para explicarem observações empíricas, construindo ferramentas que se propõem a identificar $e$ até quantificar as vivências de prazer e sofrimento e fazendo associações entre tipos de reações de defesa às diversas formas de sofrimento no trabalho. Dentre eles pode-se citar Djours (1992), Ferreira e Mendes (2001), Mendonça e Mendes (2005), Antloga e Mendes (2009), Bradburn (1969) apud Siqueira e Padovan (2008). Mais recentemente emerge uma linha de pesquisa, dentro da psicologia positiva, na qual se pretende abordar esse tema, enfocando os fatores que possam levar ao prazer no trabalho, já que existe uma crítica a cerca do predomínio do olhar do pesquisador sobre os fatores que podem levar ao sofrimento nos estudos de até então. Nessa linha pode-se citar pesquisadores como por exemplo, Seligman e Csikszentmihalyi (2000) apud Siqueira e Padovan (2008).

A dificuldade em estudar esse tema é sua natureza multidisciplinar, englobando disciplinas como psicologia, administração e sociologia. Em relação à psicologia, duas direções de estudo podem ser percebidas, as dinâmicas que são coletivas, portanto se fazem no grupo de trabalho e os fatores de personalidade individuais. Entretanto, o estudo desses dois aspectos numa organização ainda mostra-se 
insuficiente para resultar em estudos conclusivos sobre prazer e sofrimento no trabalho, há de se considerar ainda os aspectos culturais envolvidos na questão, como os elementos indutores dos afetos positivos e negativos e também dos aspectos cognitivos que levam à satisfação.

\subsection{Formulação do problema}

Qual a relação entre o perfil pessoal, social e profissional do trabalhador e as experiências de prazer e sofrimento por ele vivenciadas no trabalho?

\subsection{Objetivo Geral}

Relacionar perfil pessoal com experiências de prazer e sofrimento.

\subsection{Objetivos Específicos}

a) Descrever as características objetivas pessoais e sócio-demográficas comuns;

b) Descrever o nível de prazer e sofrimento de um grupo de trabalhadores voluntários;

c) Procurar relações entre as características sócio-demográficas e os indicadores de prazer-sofrimento do grupo de pessoas participantes da pesquisa.

\subsection{Justificativa}

As vivências de prazer e sofrimento no trabalho envolvem variáveis complexas e afetam o desempenho do trabalhador; por conseguinte refletem-se nos resultados das atividades organizacionais. Pode-se avaliar que tais vivências são provocadas por aspectos diversos, como por exemplo: (i) características pessoais, envolvendo as percepções individuais e a forma como cada pessoa responde aos estímulos do ambiente de trabalho; (ii) aspectos sociais, tanto os que envolvem o ambiente organizacional, como aqueles que envolvem as pessoas fora do ambiente de 
trabalho, (iii) estrutura organizacional e as relações de poder dela decorrentes, (iv) as condições de conforto físico no trabalho, etc.

Em meio às estruturas capitalistas observam-se casos de insatisfação e adoecimento físico e mental no trabalho, com frequência perceptível até aos olhos leigos. Vale lembrar que os resultados das organizações capitalistas são obtidos por meio da divisão do trabalho, que guarda em si fluxos de poder baseados nas hierarquias funcionais e na especialização do trabalho.

Com efeito, as diferentes fases de consolidação do capitalismo envolveram importantes mudanças nas tecnologias, na qualificação do trabalhador, nos modos de organização do trabalho e da produção, nas estratégias empresariais, nas formas de controle sobre os trabalhadores, no desempenho dos sindicatos e no papel do Estado (MERLO; LAPIS, 2007).

Recentemente, a realidade do trabalho apresenta-se adversa para muitos segmentos de trabalhadores, afetando sua saúde física e mental, em um contexto trabalhista onde se evidencia o enfraquecimento do movimento sindical, a desestruturação do Estado de Bem-Estar Social e de sua rede de políticas públicas, a desconstituição dos direitos sociais dos trabalhadores, a expansão de formas de trabalho precárias, a elevação das taxas de desemprego e o crescimento da exclusão social (LAPIS, 2002 apud MERLO; LAPIS, 2007).

Diante dos problemas de adoecimento funcional, as empresas tendem a ignorar o poder desconfortante de suas estruturas e passam a encontrar conveniência na dissociação entre os sintomas e as vivências de sofrimento no trabalho.

\footnotetext{
A consulta médica termina por disfarçar o sofrimento mental: é o processo de medicação, que se distingue bastante do processo de psiquiatrização, na medida em que se procura não-somente o deslocamento do conflito homem-trabalho para um terreno mais neutro, mas a medicação visa, além disso, a desqualificação do sofrimento, no que este pode ter de mental." (DEJOURS, 1992, p. 121)
}

Muito embora a personalidade de cada um possa explicar a forma sob a qual aparecem as descompensações e seus conteúdos (DEJOURS, 1992, p. 122), 
certos tipos de sofrimentos associam-se a determinadas categorias funcionais como um sintoma coletivo do sofrimento no trabalho.

Em Dejours (1992, p. 124-125), encontra-se o exemplo interessante da síndrome subjetiva pós-traumática, porque além de ser diagnosticada principalmente em operários da construção civil e nos trabalhadores com tarefas perigosas, ilustra o fato de que a organização do trabalho só admite o sofrimento mental no final de sua evolução: a doença mental caracterizada. Ocorre que após um acidente, um operário convencido da realidade do risco inerente à sua tarefa, naturalmente recusa-se a retornar ao trabalho, pois a consciência exata do risco presente durante o trabalho torna impossível a continuidade da tarefa. Entretanto, somente o sofrimento físico pode ser reconhecido pela organização do trabalho. Assim, recusar-se a retornar ao trabalho, por ansiedade, equivaleria à demissão. A saída então é a "medicalização" do medo, apoiada pelas cefaleias, vertigens, etc. Como regra geral, com o passar do tempo a situação do doente vai agravando-se e passa a ser tratada por psiquiatras. A invalidez e as pensões são concedidas apenas devido ao status reconhecido da doença mental.

Este estudo se propõe a pesquisar sobre as relações o perfil sócio-demográfico e as vivências de prazer e sofrimento no trabalho. Espera-se que venha a contribuir academicamente no exame do prazer e sofrimento no trabalho. Além disso, esperase contribuir para uma prática de melhores relações trabalhistas e para a construção de ambientes organizacionais mais saudáveis e mais bem adaptados às necessidades do trabalhador, sendo esse o principal fator de sucesso nas organizações. Em relação à sociedade, esta tem muito a ganhar com os avanços do conhecimento sobre prazer e sofrimento no trabalho, pois a melhoria das condições de trabalho influenciam diretamente a qualidade de vida das pessoas, tanto individualmente como coletivamente, por exemplo, implica menores custos previdenciários, maior produção agregada, maior qualidade nos serviços consumidos, uma sociedade mais justa e igualitária, e em decorrência, menos violenta. 


\section{REFERENCIAL TEÓRICO}

Estudos mais recentes sobre as vivências de prazer e sofrimento no trabalho tendem a abordar esse tema de forma bastante complexa, considerando aspectos referentes: (i) às condições concretas de trabalho, como as ergonômicas, (ii) aos relacionamentos envolvidos tanto os interpessoais como os ligados ao coletivo de trabalho, (iii) às estratégias de defesa dos trabalhadores para minimizar uma realidade de sofrimento, (iv) às variáveis subjetivas ao indivíduo, como as ligadas à sensação de bem-estar no trabalho, as respostas aos fatores estressores, a estrutura da personalidade e a história de vida de cada um. (MENDES, 1999; DEJOURS, 1992).

Neste trabalho, aborda-se o prazer e o sofrimento no trabalho sob a ótica da psicodinâmica .

Os impactos do mundo do trabalho sobre o funcionamento psíquico e sobre o comportamento dos trabalhadores vem sendo estudados mais especificamente desde o período da intensa industrialização, no início do século XX, objetivando-se diminuir as fadigas, o estresse, as insatisfações e outros tipos de perturbações sofridas pelos trabalhadores, quando submetidos à racionalização do trabalho. A partir da década de 1950, foram introduzidas, nesses estudos, variáveis psicológicas e sociais para explicar as relações entre trabalho e saúde mental (MENDES, 1999).

Em meio a esse contexto, a psicodinâmica tem suas origens. Segundo Assis e Macedo (2008), a Psicodinâmica origina-se em estudos realizados na década de 1950 , que pretendiam explicar os transtornos mentais dos trabalhadores, produzidos por modelos de gestão tayloristas. O termo psicodinâmica provém da teoria psicanalítica, e designa o estudo dos movimentos psicoafetivos gerados pela evolução dos conflitos inter e intra-subjetivos. A psicopatologia do trabalho objetiva os processos intersubjetivos envolvidos nas interpretações do trabalho pelos trabalhadores.

Para Hallack e Silva (2005), o trabalho no contexto das organizações implica a influência das subjetividades pela intersubjetividade do grupo de trabalhadores. $O$ 
trabalho numa organização proporciona a possibilidade de identificação social e cultural mediante a atmosfera de pertencimento a grupos e incorporação de valores.

Para Dejours (2004, p.27) as implicações da análise das relações entre trabalho e subjetividade feitas pela psicodinâmica do trabalho são de duas ordens: "de uma parte, compreender as conseqüências humanas da virada neoliberal; de outra, enriquecer a concepção da ação no campo político". Ainda segundo o autor:

a psicodinâmica é uma disciplina clínica que se apoia na descrição e no conhecimento das relações entre trabalho e saúde mental; a seguir, é uma disciplina teórica que se esforça para inscrever os resultados da investigação clínica da relação com o trabalho numa teoria do sujeito que engloba, ao mesmo tempo, a psicanálise e a teoria social (DEJOURS, 2004, p. 27).

\subsection{O estudo do prazer e do sofrimento no trabalho: Abordagem da psicodinâmica}

Tradicionalmente, as vivências de prazer e sofrimento no trabalho relacionadas com a organização do trabalho vêm sendo estudadas pela psicodinâmica. Tal abordagem preocupa-se em sua primeira fase, na década de 80 , com a dinâmica do sofrimento psíquico e as estratégias defensivas desenvolvidas frente ao sofrimento. $\mathrm{Na}$ segunda fase, até o início da década de 90, a psicodinâmica aborda o prazer no trabalho, direcionando-se para a saúde. Por fim, a terceira etapa enfoca o trabalho como espaço no qual o trabalhador constrói sua identidade (ANTLOGA; MENDES, 2009).

A psicodinâmica preocupa-se com os aspectos de influência mútua entre sujeito e realidade de trabalho. Nessas relações estão envolvidos tanto os aspectos simbólicos do indivíduo, referentes a sua auto-imagem e a sua identidade, os aspectos culturais e da história de vida das pessoas, como o próprio contexto organizacional, com seus meios e métodos de produção e com as relações de poder implícitas à organização do trabalho. (MENDES, 1999).

Então, as pesquisas da psicodinâmica significam um olhar para além dos estudos sobre as alterações do funcionamento físico ou psíquico ligadas ao trabalho, por 
esses não abrangerem a dinâmica das relações sujeito-realidade do trabalho, mesmo quando consideram características pessoais e contextos sociais e organizacionais. Para a psicodinâmica, tais alterações físicas e psíquicas são entendidas como sintomas do sofrimento no trabalho.

Segundo Mendes (1999), muito embora os primeiros estudos da psicodinâmica considerarem o trabalho como sendo um encontro com o sofrimento, enquanto o prazer é estudado como resultante da dinâmica de transformação do sofrimento, nada obstante o prazer também pode ser estudado como um resultado direto do trabalho, sendo alcançado mediante processos sublimativos.

Em Mendes (1999), o trabalho tem vocação para ser fonte de gratificação psíquica por ser o lugar apropriado para o contato significativo com as tarefas e o desenvolvimento das relações socioprofissionais.

\begin{abstract}
Não obstante, o prazer também pode ser estudado como resultado direto do trabalho. Por meio dos processos sublimatórios, o trabalho é fonte de gratificação psíquica, gerando prazer quando do contato significativo com determinadas tarefas e relações socioprofissionais. Este caminho para o prazer não diverge dos pressupostos conceituais da psicodinâmica, embora desloque a ênfase no estudo do sofrimento para o prazer. Assim sendo, o trabalho é um encontro com o prazer, o sofrimento instala-se quando a realidade não oferece as possibilidades de gratificação dos desejos, sendo no tipo de organização do trabalho e funcionamento organizacional específico, que encontram-se as origens deste sofrer, que não é permanente e constitui um mobilizador para a busca do prazer" (MENDES, 1999, p. 31).
\end{abstract}

O prazer e o sofrimento no trabalho são entendidos pela psicodinâmica como um constructo dialético, prazer-sofrimento, que pressupõe a atividade do trabalho como fonte capaz de gerar tanto o prazer quanto o sofrimento. Ou seja, o conceito prazersofrimento possui dois polos opostos, mas não necessariamente excludentes, os quais apresentam graduações de intensidades que variam de indivíduo para indivíduo em situações semelhantes. Esse conceito traz implícito a ideia de movimento em direção ao prazer, o que significa dizer que o sofrimento tende a ser transformado na busca pelo prazer.

Para a psicodinâmica, o trabalho é um local onde o trabalhador tem a oportunidade de realizar motivações e desejos, formados em função de sua história de vida e da 
estrutura de sua personalidade. No trabalho, o indivíduo reconhece sua identidade por meio do fazer. Assim, o trabalho pode ser um meio de satisfações concretas e simbólicas. As satisfações concretas são aquelas relativas à saúde do corpo do indivíduo, à proteção à vida, portanto. As satisfações simbólicas dizem respeito à realização do trabalhador, quando atribuem significado ao trabalho (ANTLOGA ; MENDES, 2009).

Para a psicodinâmica, o trabalhador interpreta a realidade do trabalho e a ela reage física, mental e afetivamente. A dinâmica entre a realidade psíquica e a realidade de trabalho constrói a subjetividade do trabalhador, sendo essa entendida como uma construção articulada entre psíquico e social. A saúde do trabalhador é um estado derivado do confronto entre a realidade de trabalho e as perspectivas e necessidades do trabalhador, nem sempre compatíveis. Assim, todo trabalho impõe uma carga psíquica, originada na confrontação do desejo do trabalhador e da realidade do trabalho, mas tal carga também tem suas origens na pressão atribuída pela organização do trabalho ao aparelho psíquico do trabalhador (ANTLOGA; MENDES, 2009).

Quando o trabalho permite a redução da carga psíquica e um funcionamento livre do psiquismo, torna-se fonte de gratificação, originando prazer. Caso contrário, quando o trabalho não permite articulações entre os desejos do trabalhador e a realidade, torna-se fonte de tensão e de sofrimento. Sofrimento é portanto o resultado dos conflitos intersubjetivos e intra-subjetivos dos trabalhadores com a realidade do trabalho. Assim, prazer e sofrimento são mais que conforto ou desconforto físico, mas dizem respeito ao fluxo dos processos psíquicos do indivíduo, sendo que esses fluxos são determinados pela realização ou repressão da energia psíquica na relação indivíduo-trabalho (ANTLOGA; MENDES, 2009).

Em decorrência do sofrimento no trabalho, os trabalhadores, ao buscarem manter o equilíbrio psíquico, podem desenvolver estratégias de enfrentamento do sofrimento, defensivas ou de mobilização subjetiva, como forma de minimizar ou evitar a percepção de uma realidade de sofrimento. Essas estratégias podem evitar o adoecimento no trabalho, sendo que esse ocorre quando tais estratégias falham, 
diante da impossibilidade do trabalhador mudar a organização do trabalho (DEJOURS; ABDOUCHELI, 1990 apud ANTLOGA; MENDES, 2009).

O enfrentamento do sofrimento também se dá por meio de estratégias criativas, sendo essas caracterizadas por comportamentos de cooperação, solidariedade, confiança, participação coletiva e engajamento nas discussões do grupo com finalidade de provocar mudanças (MENDES, 1999).

Muito embora os sofrimentos do trabalho sejam percebidos individualmente, eles apresentam especificidades que variam para cada categoria profissional (ANTLOGA; MENDES, 2009). Ou seja, as experiências de prazer-sofrimento são vivências subjetivas do próprio trabalhador, mas são compartilhadas coletivamente e são influenciadas pelas atividades de trabalho específicas (FERREIRA; MENDES, 2001).

Algumas estratégias defensivas foram identificadas em estudos científicos (DEJOURS; ABDOUCHELI; JAYET, 1994; MENDES; MORRONE, 2002, apud (ANTLOGA; MENDES, 2009): comportamento de isolamento psicoafetivo e profissional do grupo de trabalho; resignação; descrença; renúncia à participação; indiferença e apatia; desmotivação e desencorajamento; condutas de evitação como o absenteísmo; comportamentos agressivos de violência ou rebelião; diluição das responsabilidades, quando o trabalhador evita riscos e desafios; ativismo, quando o trabalhador se envolve em diversas situações, simultaneamente, evitando a consciência de situações desconfortáveis; presença excessiva no local de trabalho, fora do expediente; individualismo, ou seja a realização das tarefas de forma autônoma, pelos rompantes de agressividade, pela dispersão das formas de convivência e pela excessiva agressividade.

Segundo Antloga e Mendes (2009), a mobilização subjetiva é o processo que permite ao trabalhador transformar sofrimento em prazer por meio do resgate do sentido do trabalho. Sentido do trabalho é a relação entre a subjetividade do trabalhador, o saber fazer e o coletivo do trabalho. O coletivo do trabalho é o relacionamento saudável entre os trabalhadores, e ocorre independente da vontade da organização. 
A busca pelo prazer por meio da mobilização subjetiva é melhor caminho para o enfrentamento das vivências de sofrimento do trabalho, em comparação com a utilização das estratégias de defesa, porque essas estratégias, apesar de contribuírem para o equilíbrio psíquico, podem levar a processos de imobilismo e alienação do trabalhador (ANTLOGA; MENDES, 2009; FERREIRA; MENDES, 2001).

\subsection{Algumas origens das experiências de prazer e sofrimento no} trabalho: A organização do trabalho, a tarefa, a cultura organizacional, a criação das incompetências, o mecanismo de cooperação e reprovação, a injustiça no trabalho

Segundo Ferreira e Mendes (2001), o prazer no trabalho pode ser vivenciado quando o trabalho favorece à valorização e ao reconhecimento, pela realização de uma tarefa significativa e importante para a organização e a sociedade. Já as vivências de sofrimento estão associadas à divisão e à padronização de tarefas com subutilização do potencial técnico e da criatividade; rigidez hierárquica, com excesso de procedimentos burocráticos, ingerências políticas, centralização de informações, falta de participação nas decisões e não-reconhecimento;pouca perspectiva de crescimento profissional.

As relações entre a significação da tarefa e o sofrimento são abordadas por Dejours (1992), Dejours $(1993,1994)$ apud Mendes e Ferreira (2010), inclusive porque essas influenciam a formação da auto-imagem do trabalhador.

Dejours (1995, 1997, 1998) apud Ferreira e Mendes (2001) considera que o sofrimento tem origem na organização do trabalho, na mecanização e robotização das tarefas, na adaptação à cultura organizacional, além disso, na criação de incompetências, ou seja o trabalhador se sente incapaz de enfrentar as situações do trabalho, quando há a retenção da informação e nas novas formas de sofrimento, a cooperação e a reprovação. O mecanismo de cooperação e reprovação diz respeito 
às novas tarefas que o trabalhador tem de desempenhar, sendo que esse trabalho a mais pode desencadear a sua própria reprovação, no sentido de uma traição a si mesmo, o que pode desestabilizar sua identidade.

Para Dejours (1992), a organização do trabalho não consiste somente na divisão das tarefas, mas também as hierarquias, as repartições de responsabilidades e os sistemas de controle. Os efeitos da relação dinâmica entre as pessoas e a organização do trabalho recaem sobre o aparelho psíquico: "a organização do trabalho exerce, sobre o homem, uma ação específica, cujo impacto é o aparelho psíquico" (DEJOURS, 1992, p.133). As formas de manifestação do sofrimento diferem segundo os diferentes tipos de organização do trabalho (DEJOURS, 1992).

A abordagem da psicodinâmica entende as vivências de prazer e sofrimento no trabalho como um fenômeno mediador entre o social e o psíquico, ou seja como fenômeno resultante das interação entre organização do trabalho e trabalhador. Ampliando-se este conceito para um contexto organizacional específico percebe-se a importância que a cultura organizacional tem para a formação das vivências de prazer-sofrimento, porque ela estabelece padrões de funcionamento organizacional conforme os valores que carrega (MENDES, 1999).

Os valores organizacionais podem originar prazer no trabalho se favorecem à organização do trabalho flexível, aberta a negociações das regras e normas dos processos de trabalho, à participação dos trabalhadores nas decisões e à gestão coletiva das necessidades individuais e organizacionais. Entretanto, se os valores organizacionais originam uma organização do trabalho intolerante às críticas e às negociações das normas e regras, pode favorecer ao sofrimento (MENDES, 1999).

Além dos fatores já citados, estudos de Mendonça e Mendes (2005) indicam que a injustiça no trabalho gera sofrimento, e esse funciona como mediador às retaliações do trabalhador. O tratamento injusto constitui-se em desrespeito e provoca a indignação do trabalhador. A pesquisa encontrou, no caso prático estudado, as evidências da existência de dois papéis desempenhados pelas reações às injustiças, como apontados na literatura: (i) o positivo, de proteção ao indivíduo contra afetos 
negativos que podem levar ao adoecimento, (ii) e o negativo, fator de alienação e imobilidade em relação à realidade.

As reações às injustiças em forma de retaliação organizacional podem ser entendidas como estratégias contra o sofrimento, visando o resgate do equilíbrio interno do trabalhador. Assim, tal comportamento sofre influência dos atributos pessoais, quando expressados de maneira sutil ou agressiva pelo retaliador, em resposta à percepção de injustiça no trabalho, contra a própria organização ou contra as pessoas que dela participam. A retaliação pode ocorrer em diferentes contextos, abrangendo relações interpessoais, organizacionais ou societais (MENDONÇA, 2003, apud MENDONÇA; MENDES, 2005).

\subsection{O trabalhar: da experiência singular à ação coletiva}

Para a psicodinâmica, o trabalho é o trabalhar, ou seja a ação de trabalhar, englobando nesse trabalhar todos os recursos empregados pelo trabalhador, tanto os visíveis quanto os invisíveis.

\footnotetext{
o trabalho é aquilo que implica, do ponto de vista humano, o fato de trabalhar: gestos, saber-fazer, um engajamento do corpo, a mobilização da inteligência, a capacidade de refletir, de interpretar e de reagir às situações; é o poder de sentir, de pensar e de inventar (...) é o <<trabalhar >>, isto é, um certo modo de engajamento da personalidade para responder a uma tarefa delimitada por pressões (materiais e sociais). (DEJOURS, 2004, p.28).
}

Significa dizer que o trabalho, naquilo que ele tem de essencial, não pertence ao mundo visível (DEJOURS, 2004, p. 30)

O trabalhar não encontra adequação perfeita entre as prescrições (instruções e procedimentos) que a organização do trabalho propõe para se alcançar a realização da tarefa e a realidade concreta da situação. Trabalhar é superar a discrepância entre o prescrito e o real, sempre existente. O trabalhador, por sua vez, percebe essa discrepância como fracasso. O mundo real apresenta-se ao sujeito como um efeito surpresa desagradável, ou seja apresenta-se de um modo afetivo, causando 
sentimentos de impotência, irritação, cólera, decepção e esmorecimento, o sofrimento afetivo. Mas é esse sofrimento o ponto de partida para a busca dos meios para a agir de forma a superar a resistência do real. Então, o sofrimento é também a origem da inteligência no trabalho que parte do mundo real para transformá-lo. Dessa forma, a inteligência no trabalho é essencialmente a inteligência do corpo, uma vez que se origina do sofrimento, e não existe sofrimento sem um corpo, assim como também acontece no trabalho intelectual. (DEJOURS, 2004).

Trabalhar não é somente produzir; é também, transformar a si mesmo e, pode oferecer uma ocasião à subjetividade para se testar e até mesmo se realizar. Mais profundo ainda, Dejours (2004, p.31) considera a centralidade do trabalho no funcionamento psíquico, o que coloca o trabalhar como uma "condição transcendental de manifestação absoluta da vida". Entretanto, "as novas formas de organização do trabalho, de gestão e de administração específicos do neoliberalismo é, nolens volens, o futuro do homem que está comprometido" (DEJOURS, 2004, p.31).

Como exemplo de quão longe podem ir as práticas nocivas dentro da organização do trabalho, Gaulejac (2007) apud Santos et al. (2010), comenta sobre a gestão do afetivo, modelos gerencialistas cada vez mais sofisticados, os quais pressionam e mobilizam subjetivamente o indivíduo para que venha a aceitar a empresa como único local em que se pode ser feliz. Já Enriquez (1999) apud Santos et al. (2010), comenta sobre a psicologização, processo em que o indivíduo assume a culpa por não cumprir as exageradas exigências da organização e aceita ser desligado.

O trabalho é também uma forma de relação social, uma vez que se desenvolve num ambiente coletivo, assim, o real do trabalho não é somente o real da tarefa, mas engloba ainda o real do mundo social, com suas relações desiguais, de poder e dominação, onde as subjetividades singulares precisam ser empregadas. Nesse sentido, as organizações do trabalho encontram o desafio de lidar com as inteligências particulares na realização das atividades, uma vez que divergências entre estilos de trabalho podem ocasionar a coesão do coletivo de trabalho. Então, a 
organização do trabalho esforça-se para coordenar as inteligências, definindo a cada um tarefas específicas e prerrogativas limitadas (DEJOURS, 2004).

Desde a tradição taylorista, as organizações do trabalho são essencialmente consagradas à divisão social e técnica do trabalho, definindo a cada um tarefas, atribuições e prerrogativas limitadas (DEJOURS, 2004, p. 32)

Mas, ainda assim, para que o processo de trabalho funcione, as prescrições precisam ser ajustadas ao real. Então, à coordenação (prescrita), os trabalhadores respondem com a cooperação (efetiva). Muito embora a cooperação também represente uma limitação da atuação individual, é na cooperação que o trabalhador se envolve no debate coletivo e dá testemunho de sua experiência, esforçando-se para tornar visíveis suas contribuições. Então existe uma renúncia do trabalhador em favor do viver junto e da cooperação, que por sua vez pressupõe um compromisso que ao mesmo tempo é técnico e social. Além disso, a falta de acordos coletivos levam à violência, e por outra parte o coletivo pode colocar à disposição recursos específicos a serviço do aprimoramento das subjetividades singulares, como por exemplo o reconhecimento do grupo pela inteligência no saber fazer testemunhada. Esse reconhecimento, por sua vez, confere ao trabalhador um sentimento de pertencimento (DEJOURS, 2004).

\begin{abstract}
se o intuito da ação política é, de fato, a celebração da vida e não o culto do poder, ou melhor, se a luta contra a dominação tem, de fato, como finalidade a celebração da vida e não o gozo do poder ou a promoção do individualismo consumista, então a ação e a luta deverão se dar como meta fazer da organização do trabalho um objetivo primário da deliberação política (DEJOURS, 2004, p.33).
\end{abstract}

\title{
2.4 Abordagem quantitativa do constructo prazer-sofrimento
}

O constructo prazer-sofrimento vem sendo estudado pela psicodinâmica de forma qualitativa desde a década de 1980. No Brasil, Mendes (1999) realizou o primeiro estudo abordando esse assunto por meio de uma escala. 
Para tanto partiu-se da organização dos valores organizacionais em três dimensões com pólos opostos: (i) Autonomia versus Conservação. (ii) Estrutura igualitária versus Hierarquia; (iii) Harmonia versus domínio. As variáveis prazer-sofrimento formam um único constructo composto por três fatores: valorização e reconhecimento, que medem o prazer, e desgaste com o trabalho, que mede o sofrimento. (MENDES, 1999)

A autonomia se refere ao grau de independência e de inciativa experimentado pelo trabalhador que é tolerado pela organização do trabalho. A manutenção significa o grau de manutenção do status quo imposto pela organização, o que implica o grau de restrição às ações dos trabalhadores. O igualitarismo se refere ao grau de importância dada ao bem de todos em relação aos interesses individuais e organizacionais. A hierarquia se refere ao grau de legitimação das relações de poder. A harmonia se refere ao grau de interação e ajustamento entre a organização e o ambiente externo. O domínio se refere ao grau de auto-afirmação e domínio em relação ao meio social e natural que envolve a organização (MENDES, 1999). 


\section{MÉTODOS E TÉCNICAS DE PESQUISA}

\subsection{Descrição geral da pesquisa}

O estudo proposto procura por relações entre perfis sócio-demográficos e as experiências de prazer e sofrimento no trabalho, a partir da realidade das pessoas que integram a amostra populacional analisada. Desse modo, detém natureza descritiva e explicativa. Para tanto, lança mão de pesquisa de campo, baseada na aplicação de um questionário para coleta dos dados primários. Tais dados foram analisados quantitativamente. Em relação à unidade de análise, procura-se por grupos de pessoas com características sócio-demográficas semelhantes, que apresentem níveis de prazer e sofrimento no trabalho também semelhantes. Em relação ao horizonte temporal, a pesquisa é transversal, pois destina-se a investigar as manifestações dos entrevistados em determinado momento e não de maneira evolutiva.

\subsection{População e amostra estudada}

A população estudada é formada pelas pessoas que desenvolvem atividade de trabalho no Distrito Federal ou proximidades, nos setores público ou privado.

Por conveniência, para a pesquisa de campo, elegeu-se uma amostra de 50 respondentes, dentre eles: (i) bancários dos setores público e privado, (ii) estudantes da Universidade de Brasília também trabalhadores; (iii) estudantes de outras instituições de ensino superior também trabalhadores que encontravam-se na Universidade de Brasília nos dias em que a pesquisadora esteve coletando dados e (iv) aplicação do questionário a estudantes trabalhadores da Universidade Estadual de Goiás mediante envio das respostas via e-mail. 


\subsection{Caracterização do Instrumento de pesquisa}

A coleta de dados se deu por meio de (i) questionário utilizado e revalidado por Resende (2003), se constituindo de duas escalas, uma para valores e outra para indicadores de prazer-sofrimento no trabalho e (ii) mais um questionário para levantamento dos dados demográficos, similar ao aplicado por Resende (2003). Entretanto, para as análises, não se considerou todo o questionário, excluindo-se a parte concernente aos valores.

Mais especificamente, para mensuração das vivências de prazer e sofrimento no trabalho foi utilizado o instrumento criado por Mendes (1999), cuja pontuação é feita seguindo uma escala de freqüencia, tipo Likert, de 5 pontos, com 30 itens distribuídos em 4 fatores: Gratificação (alfa de Cronbach = .89), Liberdade (alfa = . 82), Insegurança (alfa $=.80$ ) e Desgaste (alfa $=.86)$. Em tal instrumento os indicadores de prazer-sofrimento se fundamentam na Escala de Indicadores de Prazer e Sofrimento no Trabalho - EIPST, sendo os fatores de prazer Gratificação e liberdade e os fatores de sofrimento insegurança e desgaste (RESENDE, 2003).

Segundo Resende (2003, p.86), "o fator Gratificação diz respeito ao sentimento de que o trabalho tem sentido e valor por si mesmo, é importante e significativo para a organização e sociedade". A gratificação envolve a realização no trabalho, que significa o sentimento de satisfação e plenitude experimentado nas ações do cotidiano do trabalho, em face do reconhecimento social que a execução das tarefas traz ao trabalhador.

Segundo Resende (2003, p.88), "Liberdade é definida como o sentimento de estar livre para pensar, organizar e falar sobre o trabalho, considerando-se que o modo particular de trabalhar é reconhecido pelas chefias e colegas". Mas Resende (2003, p.100) também define Liberdade de forma que transparece a relação entre Realização e Liberdade: "O fator Liberdade é definido como o sentimento de ser aceito e admirado no trabalho e de ter liberdade para nele expressar sua individualidade no trabalho". Então, a vivência da Liberdade implica a da Realização 
em algum nível, porque na ausência de aceitação e admiração não se pode vivenciar a Liberdade.

Segundo Resende (2003, p.88): "Insegurança é vivenciada pelo receio de perder o emprego e por não se conseguir atender às expectativas relacionadas à competência profissional, exigências de produtividade e pressões do trabalho". Portanto, Insegurança não se origina em questões pessoais, mas é provocada pela organização do trabalho.

Segundo Resende (2003, p. 88-89) "Desgaste é definido como o sentimento de que o trabalho causa estresse, sobrecarga, tensão emocional, cansaço, ansiedade, desânimo e frustração". Além disso, a psicodinâmica considera o fator Desgaste como reflexo da organização do trabalho e não originado em fatores pessoais. Portanto qualquer tipo motivacional pode vivenciar tal sentimento.

Abaixo, os itens que compõem os fatores de prazer e sofrimento.

Quadro 1: Itens dos fatores de prazer

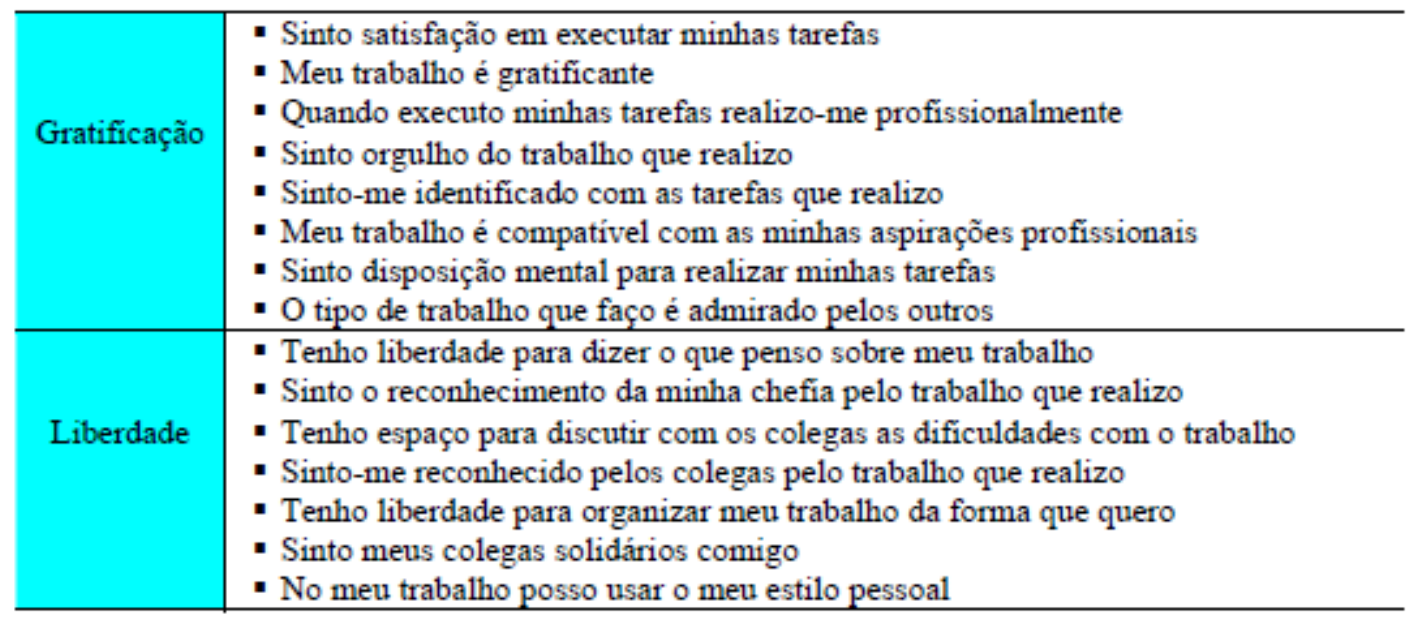

Fonte: Resende (2003,p.75) 
Quadro 2: Itens dos fatores de sofrimento

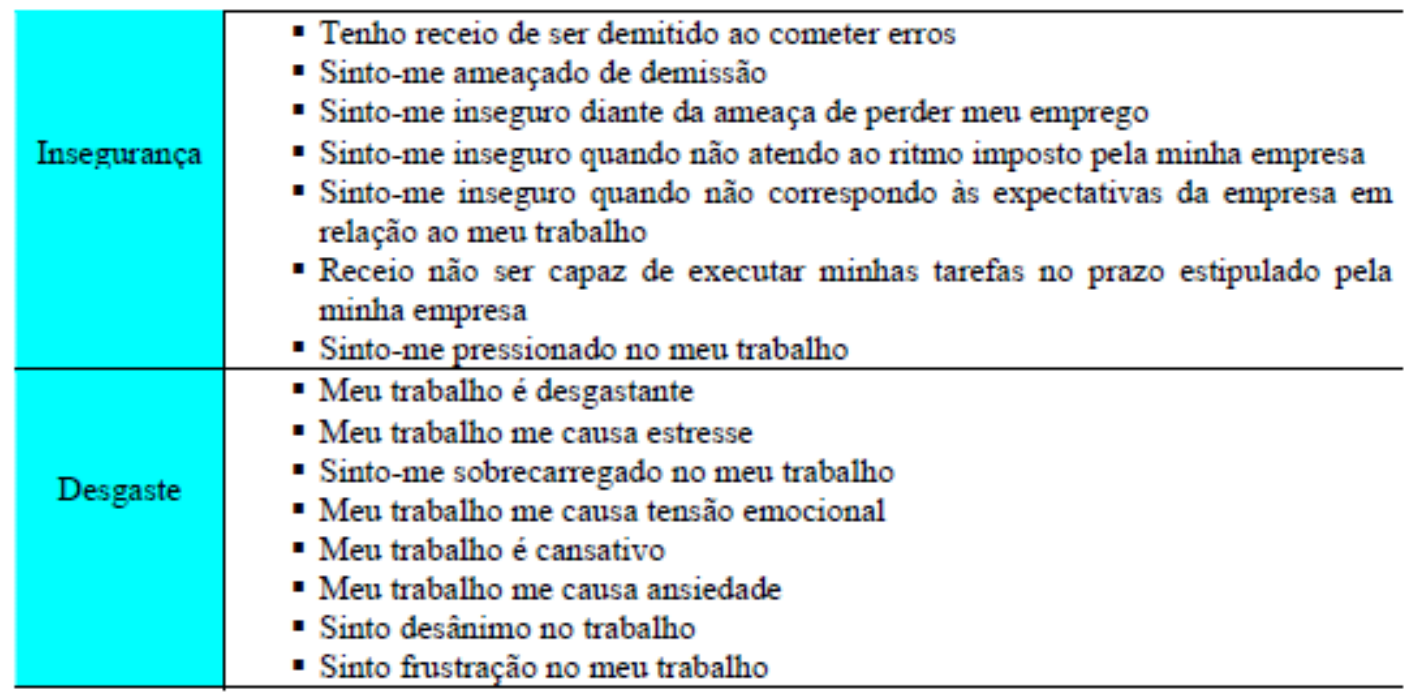

Fonte: Resende (2003,p.75).

\subsection{Procedimentos de coleta e de análise de dados}

\subsubsection{Procedimento}

A coleta de dados realizou-se mediante: (i) visita da pesquisadora a algumas agências bancárias no DF localizadas na cidade satélite de Águas Claras e mediante abordagem direta da pesquisadora aos respondentes nas vias públicas do Setor Bancário Sul, Brasília (DF), por ocasião do movimento grevista ocorrido em outubro de 2010; (ii) abordagem direta da pesquisadora nas instalações físicas da Universidade de Brasília (UNB); (iii) troca de arquivos por meio eletrônico.

Os questionários foram entregues pela pesquisadora aos respondentes: (i) em seus locais de trabalho, para retorno posterior pelo próprio respondente mediante depósito em caixa postal especificada; (ii) em vias públicas, nas proximidades de agências bancárias e dentro das instalações físicas da UNB, mediante abordagem direta da pesquisadora, e recolhimento imediato das respostas; (iv) por intermédio de terceiros, isentos em relação ao público-alvo, devidamente orientados pela pesquisadora, e que se comprometeram em respeitar o sigilo dos dados e o 
anonimato do respondente; e (v) por e-mail, segundo escolha do próprio respondente; nesses casos, a entrega das respostas também se deu por e-mail, mediante troca de arquivo eletrônico.

Em todos os casos, o questionário foi precedido por uma carta de apresentação, cujo texto esclarecia sobre aspectos da pesquisa como a instituição a que ela se vincula e seus objetivos, além de esclarecer sobre o anonimato dos respondentes e o uso dos dados exclusivamente para subsidiar a pesquisa em questão.

Nos casos em que o questionário foi deixado para ser entregue aos respondentes por terceiros, além da carta de apresentação e instruções de preenchimento, o formulário contou com um campo dedicado ao enquadramento do respondente dentro dos cinco grupos de público-alvo admitidos: 1-Bancário(a); 2-Bancário(a) e estudante da UNB; 3-Bancário(a) e estudante de nível superior de outra instituição de ensino; 4-Estudante da UNB que trabalha em ramo diverso ao bancário; 5Estudante de nível superior de outra instituição de ensino que trabalha. Duas pesquisas foram descartadas na coleta de dados por falta do preenchimento desse campo, para evitar respondentes fora da amostra admitida. Ou seja, esse procedimento objetivou assegurar algum controle por parte da pesquisadora sobre os questionários aplicados por terceiros.

Tantas categorias de público-alvo se justificam pela expansão gradual da abrangência do público-alvo ao longo da coleta de dados, em virtude das dificuldades em se contabilizar a quantidade de respondentes mínima estabelecida no projeto da pesquisa. No início da coleta, a pesquisadora procurou concentrar-se na categoria dos bancários e nos estudantes trabalhadores da UNB, buscando maior rapidez e foco na coleta de dados. Ocorre que durante o período de coleta, os bancários permaneceram em greve durante 15 dias, o que dificultou não só o recolhimento dos questionários já distribuídos como também a obtenção de novos respondentes. Então, optou-se por alargar o foco do público-alvo em favor da obtenção do número mínimo de respondentes.

Não houve limitação de tempo no preenchimento dos questionários. As entregas dos formulários se deu mediante manifestação da pessoa abordada em querer participar 
da pesquisa, então todos os participantes foram voluntários e interessados pelo tema do estudo. Não houve cobranças em relação à entrega dos questionários respondidos; ou seja, as pessoas que receberam o questionário ficaram inteiramente à vontade para devolverem suas respostas.

Os dados foram coletados durante o mês de outubro/2010.

\subsubsection{Análise dos dados}

Após tabulação das respostas em planilha eletrônica (Calc do BrOffice), verificou-se que o respondente número 5 havia atribuído a pontuação máxima para a grande maioria dos itens do questionário, o que poderia causar desvios nas análises. Assim, retirou-se o conjunto de suas respostas da base de dados, que dessa forma passou a contar com 50 respondentes.

As médias individuais de cada respondente para indicadores de prazer e sofrimento foram calculadas em planilha eletrônica (Calc do BrOffice).

Os valores atribuídos aos indicadores de prazer e sofrimento, obtidos pela amostra representam a média das médias individuais para tais indicadores. Foi utilizado o software SPSS (Statistical Pack of Social Science) versão 17.0 for Windows para realizar: (i) os cálculos dos indicadores de prazer-sofrimento (médias) e (ii) as análises de correlação.

Em relação às variáveis demográficas, retirou-se da base de dados a variável nacionalidade, porque todos os respondentes são brasileiros. Tal variável foi inserida no questionário para detectar presença de respondentes estrangeiros, considerando-se que a região de aplicação dos relatórios, Brasília (DF) e proximidades, abriga muitos estrangeiros em virtude de sua condição de capital da República. 
Para a análise dos indicadores de prazer-sofrimento observou-se os seguintes intervalos: (i) abaixo de 2,5 - baixa vivência do fator; (ii) entre 2,5 e 3,5 - vivência moderada; (iii) acima de 3,5 - alta vivência do fator (RESENDE, 2003).

$\mathrm{Na}$ interpretação dos indicadores de prazer e sofrimento considera-se o binômio prazer-sofrimento dentro das quatro possibilidades teóricas: (i) Prazer alto e sofrimento baixo significando um bom estado de saúde; (ii) Sofrimento alto e prazer baixo significando um estado de saúde grave; (iii) Prazer e sofrimento moderados significando um estado crítico, o que pode significar o uso de estratégias defensivas para enfrentar o sofrimento. (iv) Prazer alto e sofrimento moderado significando um estado de alerta, podendo indicar o uso de mobilização subjetiva (RESENDE, 2003, p. 79-80). 


\section{RESULTADOS E DISCUSSÃO}

\subsection{Estatística Descritiva}

As condições e possibilidades verificadas na coleta de dados implicaram a concentração dos respondentes em relação à categoria profissional, $60 \%$ são bancários, além disso ocorreu a limitação geográfica uma vez que $82 \%$ dos respondentes declararam residir no DF. Tais aspectos da amostra provavelmente influenciaram o alto percentual de 92\% (93,9\% das respostas válidas) referente aos trabalhadores do setor de serviços. Segundo Resende (2003), no DF, 80\% da mãode-obra está concentrada no setor de serviços, devido a grande concentração de funcionários públicos, sendo residual a participação do setor industrial. Ainda segundo Resende (2003), a categoria dos bancários ocupa boa parte dos postos de trabalho do DF, cerca de $4,1 \%$ em 2003, principalmente porque as sedes dos grandes bancos federais localizam-se em Brasília. Os demais respondentes localizam-se $2,0 \%$ na indústria e $4,0 \%$ no setor agrícola/pecuário.

O local da coleta de dados, Brasília e proximidades, reconhecidamente conta com pessoas de muitas nacionalidades e naturalidades diferentes, pois trata-se da capital do país. Assim, abriga muitas embaixadas, atrai migrantes de outras regiões do Brasil e imigrantes de outros países. Apesar de tal diversidade, os respondentes da pesquisa são todos brasileiros, muito embora provenientes de todas as regiões do Brasil. Os brasilienses representam a maioria, com 18 respondentes, $36 \%$ da amostra. Brasília também conta com a maior renda per capita do Brasil, o que se refletiu na amostra, pois 26 pessoas (52\%) declararam rendimentos superiores a 08 salários mínimos - valor do salário mínimo à época da pesquisa: $R \$ 510,00$. 


\begin{tabular}{|c|c|c|c|}
\hline Dados & Grupos & $\begin{array}{c}\text { Nr. } \\
\text { Resp. }\end{array}$ & $\%$ \\
\hline \multirow[b]{2}{*}{ Público-alvo } & Bancários & 30 & $60 \%$ \\
\hline & $\begin{array}{l}\text { Estudantes trabalhadores em ramo } \\
\text { diverso ao bancário }\end{array}$ & 20 & $40 \%$ \\
\hline \multirow{4}{*}{ Idade } & Entre 18 e 30 anos & 18 & $36 \%$ \\
\hline & Entre 31 e 40 anos & 11 & $22 \%$ \\
\hline & Entre 41 e 50 anos & 16 & $32 \%$ \\
\hline & De 51 em diante & 5 & $10 \%$ \\
\hline \multirow{2}{*}{ Sexo } & Feminino & 21 & $42 \%$ \\
\hline & Masculino & 29 & $58 \%$ \\
\hline Nacionalidade & Brasileira & 50 & $100 \%$ \\
\hline \multirow{5}{*}{ Naturalidade } & Centro-oeste & 20 & $40 \%$ \\
\hline & Sudeste & 12 & $24 \%$ \\
\hline & Nordeste & 10 & $20 \%$ \\
\hline & Sul & 6 & $12 \%$ \\
\hline & Norte & 2 & $4 \%$ \\
\hline \multirow{3}{*}{ Local de residência } & DF & 41 & $82 \%$ \\
\hline & $\mathrm{GO}$ & 6 & $12 \%$ \\
\hline & $\mathrm{PA}$ & 2 & $4 \%$ \\
\hline \multirow{5}{*}{ Tempo de serviço } & Até 5 anos & 15 & $30 \%$ \\
\hline & De 6 a 10 anos & 10 & $20 \%$ \\
\hline & De 11 a 20 anos & 4 & $8 \%$ \\
\hline & De 21 a 30 anos & 18 & $36 \%$ \\
\hline & Mais de 31 anos & 3 & $6 \%$ \\
\hline \multirow{3}{*}{ Tipo de instituiçẫo } & Organizaçẫo pública & 10 & $20 \%$ \\
\hline & Empresa privada & 9 & $18 \%$ \\
\hline & $\begin{array}{l}\text { Empresa pública de direito } \\
\text { privado/Ec onomia mist a/Estatal }\end{array}$ & 31 & $62 \%$ \\
\hline \multirow{3}{*}{ Setor de atuaçẫo da instituiçẫo } & Serviços & 46 & $92 \%$ \\
\hline & Indústria & 1 & $2 \%$ \\
\hline & Agrícola/pecuário & 2 & $4 \%$ \\
\hline \multirow{2}{*}{ Trabalha na área de formação } & Sim & 26 & $52 \%$ \\
\hline & Nẫo & 24 & $48 \%$ \\
\hline \multirow{3}{*}{ Nivel de escolaridade } & Nivel superior incompleto & 20 & $40 \%$ \\
\hline & Nivel superior completo & 9 & $18 \%$ \\
\hline & Nivel pós-graduaçẫo & 20 & $40 \%$ \\
\hline \multirow{4}{*}{ Nivel de renda } & Até 03 salários mínimos & 10 & $20 \%$ \\
\hline & De 03 até 05 salários mínimos & 10 & $20 \%$ \\
\hline & De 05 até 08 salários mínimos & 4 & $8 \%$ \\
\hline & Superior a 08 salários mínimos & 26 & $52 \%$ \\
\hline \multirow{2}{*}{$\begin{array}{l}\text { Responsabilidade sobre a } \\
\text { família }\end{array}$} & Chefe de família & 36 & $72 \%$ \\
\hline & Nẫo-chefe de família & 14 & $28 \%$ \\
\hline \multirow{4}{*}{ Dependentes } & Nenhum & 23 & $46 \%$ \\
\hline & Até 03 dependentes & 23 & $46 \%$ \\
\hline & De 04 a 05 dependentes & 4 & $8 \%$ \\
\hline & Mais de 05 dependentes & 0 & $0 \%$ \\
\hline \multirow{4}{*}{ Estado civil } & Solteiro & 21 & $42 \%$ \\
\hline & Casado/Uniẫo estável & 25 & $50 \%$ \\
\hline & Separado/Divorciado & 3 & $6 \%$ \\
\hline & Viúvo & 1 & $2 \%$ \\
\hline
\end{tabular}


A amostra foi caracterizada mediante a verificação de suas médias para os indicadores de prazer e sofrimento, conforme apresenta a tabela 2, abaixo.

Tabela 2: Médias dos fatores de prazer-sofrimento

\begin{tabular}{clrrr}
\hline \multirow{2}{*}{ Fator } & Média & \multicolumn{2}{c}{$\begin{array}{c}\text { DP } \\
\text { (Std.Deviation) }\end{array}$} & $\begin{array}{r}\text { Erro (Std.Error } \\
\text { of Mean) }\end{array}$ \\
\hline \multirow{2}{*}{ Prazer } & Gratificação & 3,49 & 0,85 & 0,120 \\
& Liberdade & 3,31 & 0,81 & 0,115 \\
\multirow{2}{*}{ Sofrimento } & Desgaste & 2,95 & 0,84 & 0,119 \\
& Insegurança & 2,26 & 0,85 & 0,120 \\
\hline
\end{tabular}

Conforme os parâmetros já discutidos na metodologia, a amostra apresenta vivência moderada nos quatro fatores $(2,5 \leq$ média $\leq 3,5)$, sendo os indicadores de prazer (Gratificação e Liberdade) um pouco maiores do que os de sofrimento (Desgaste e Insegurança). Esse resultado, já previsto pela literatura conforme Resende (2003), como já comentado na metodologia, indica o possível uso de estratégias defensivas para enfrentar o sofrimento, uma vez que o sofrimento aparece moderado em meio a existência de um prazer também moderado. Em outras palavras, o sofrimento pode estar sendo contido de alguma forma e o prazer pode não estar sendo suficiente para neutralizar tal sofrimento. Entretanto, esse enfrentamento pode não estar se dando mediante o uso de Mobilização Subjetiva, mas sim pelo uso de estratégias defensivas, porque o prazer aparece de forma moderada e não alta.

\subsection{Correlações}

Foram realizadas análises de correlação entre os dados sócio-demográficos e os indicadores de prazer e sofrimento. Apenas o fator Insegurança apresentou correlações significativas (para $p \leq 0,05$ ), conforme quadro abaixo. 
Quadro 3: Correlaçỗes significativas

\begin{tabular}{|l|l|}
\hline & \multicolumn{1}{|c|}{ Insegurança } \\
\hline \multirow{4}{*}{ Sexo } & Correlaçẫo de Pearson: $r=-0,388$ \\
\cline { 2 - 2 } & $\mathrm{P}=0,005$ \\
\cline { 2 - 2 } & Intensidade: Correlaçẫo Moderada \\
\hline \multirow{3}{*}{ Renda } & Correlaçẫo de Pearson $=-0,311$ \\
\cline { 2 - 2 } & $\mathrm{P}=0,028$ \\
\cline { 2 - 2 } & Intensidade: Correlaçẫo Moderada \\
\hline
\end{tabular}

Verifica-se que a as correlações são negativas. "Um relacionamento negativo ( $r$ é -) significa que a valores altos (baixos) de uma variável correspondem valores baixos (altos) da outra" (STEVENSON, 1981, p. 369). Ambos os casos observados indicam correlação moderada, o que significa dizer que a variação de uma variável nem sempre vai explicar a variação da outra.

No caso da variável sexo (1-feminino e 2-masculino), a correlação sugere que o fator Insegurança tende a ser vivenciado com mais intensidade pelas mulheres, como reforça o quadro de frequências abaixo, onde observa-se a ausência de altas vivências de Insegurança para os homens, além disso eles apresentam maior frequência em relação às baixas vivências para o fator em questão.

Quadro 4: Frequências: Insegurança e sexo

\begin{tabular}{|c|c|c|c|}
\hline & \multicolumn{3}{|c|}{ Insegurança } \\
\hline & Baixa & Moderada & Alta \\
\hline Sexo feminino & 10 & 6 & 5 \\
\hline Sexo masculino & 25 & 4 & 0 \\
\hline
\end{tabular}

Em relação à renda, a análise dos dados sugere que maiores rendas podem contribuir para menores indicadores de Insegurança. Essa suposição também encontra amparo no quadro de frequências abaixo, onde se verifica, para as pessoas mais bem remuneradas, a maior frequência de uma baixa vivência do fator Insegurança e também nenhum caso de alta vivência do fator Insegurança. 
Quadro 5: Frequências: Insegurança e renda

\begin{tabular}{l|r|r|r|}
\hline \multirow{2}{*}{ Renda } & \multicolumn{3}{|c|}{ Insegurança } \\
\cline { 2 - 4 } Até 3 salários mínimos & Baixa & \multicolumn{1}{|c|}{ Moderada } \\
\hline De 3 a 5 salários mínimos & 4 & 4 & 2 \\
\hline De 5 a 8 salários mínimos & 7 & 1 & 2 \\
\hline Maior que 8 salários mínimos & 2 & 1 & 1 \\
\hline
\end{tabular}

Como visto anteriormente, Resende (2003) comenta que o fator Insegurança não se origina em questões pessoais, mas é provocada pela organização do trabalho.

Entretanto, a análise de correlação apontou alguns aspectos sócio-demográficos relacionados ao fator Insegurança. Uma leitura possível de tal situação seria a de que alguns dos aspectos da Insegurança esboçam as condições sociais do indivíduo, que de alguma forma interferem em seu desempenho profissional, atividade produtiva ou recompensa pelo trabalho. Os itens sócio-demográficos, se considerados no atual contexto social onde os trabalhadores sofrem pressões da acirrada concorrência e do desemprego, podem transparecer a carga de preocupações que embutem.

Em particular, no Brasil, a categoria dos bancários, maioria entre os respondentes, vem sofrendo fortes impactos das reestruturações produtivas desde 1990 (SANTOS et al , 2010).

No Brasil, o setor bancário foi um dos primeiros a sofrer os impactos dos novos tempos, no início dos anos 1990, em função da maior relevância do mercado financeiro, em escala global, e da forte competição entre as empresas do setor (Laranjeira, 1997). Segnini (1999) esclarece que as reestruturações produtivas nos bancos resultaram no fechamento de inúmeras agências (as menos lucrativas); as que restaram, sofreram fortes enxugamentos e a terceirização dos serviços foi intensificada, fatos esses que modificaram profundamente a estrutura do setor e reduziram postos de trabalho (SANTOS et al., 2010, P. 927). 


\section{CONCLUSÕES E RECOMENDAÇÕES}

O presente estudo objetiva investigar como se relacionam as características sóciodemográficas dos trabalhadores e suas experiências de prazer e sofrimento no trabalho. Assim, com base nas análises efetuadas sobre os dados colhidos em pesquisa de campo, com 50 trabalhadores escolhidos aleatoriamente dentre 0 universo de bancários e estudantes trabalhadores, infere-se o que se segue.

Os resultados obtidos apontam a existência das vivências de sofrimento no trabalho, porém de forma moderada. Isso não significa que o sofrimento demonstrado é aquele cujo trabalhador consegue transformá-lo em prazer, mediante a superação dos obstáculos advindos do embate que o trabalhador tem com as situações reais, na execução de suas atividades e no convívio social. Nesse caso, o sofrimento estaria sendo transformado mais eficientemente em prazer, indicando altas vivências de prazer e baixas de sofrimento e contemplando de forma positiva o trabalhador, a organização do trabalho e a convivência social dentro do ambiente de trabalho.

Moderadas vivências de prazer e sofrimento, como mostram os resultados dessa pesquisa, permitem considerar a hipótese de estar havendo o enfrentamento do sofrimento mediante as estratégias Defensivas. Como já se viu, essas estratégias não são tão eficientes na transformação do sofrimento, mas permitem restaurar o equilíbrio do trabalhador para que ele não adoeça. A suposição do uso das estratégias defensivas ao invés da mobilização subjetiva torna-se mais interessante se inserida no contexto de greve ocorrida durante o período de coleta de dados.

Ou seja, em período propício às manifestações da mobilização subjetiva por parte do trabalhador, ainda assim, as estratégias defensivas parecem ser mais apropriadas para explicarem os resultados da pesquisa, o que sugere a manifestação dos efeitos dessas estratégias sobre o indivíduo: a alienação, a apatia em relação a sua própria condição de vida.

Segundo as análises realizadas, as vivências de prazer e sofrimento parecem não apresentar relacionamentos fortes com os dados sócio-demográficos. Percebeu-se apenas duas correlações moderadas entre o fator de sofrimento Insegurança e as 
variáveis sexo e renda. Assim, não observou-se ocorrência de correlações válidas para os três outros fatores considerados: Gratificação e Liberdade, ambos fatores de Prazer, e Desgaste, fator de Sofrimento.

A influência das variáveis demográficas sobre Insegurança aparentemente pode ir de encontro ao entendimento da literatura, que considera Insegurança um fator puramente associado à organização do trabalho. Entretanto, analisando alguns fatores definidores do perfil social e pessoal do trabalhador dentro de um contexto social mais amplo, é possível considerar que tais fatores podem aumentar a importância de Insegurança nas vivências de prazer-sofrimento do trabalhador. Por outro lado, a organização do trabalho, vista num organismo maior que é a sociedade, interfere na amplitude do acesso social que as pessoas dispõem, e o nível desse acesso vai formar, juntamente com outras variáveis, o perfil pessoal e social do trabalhador.

As poucas relações verificadas entre os perfis sócio-demográficos e vivências de prazer-sofrimento no trabalho podem se justificar pela predominância dos fatores que influenciam tais vivências como inerentes à organização do trabalho, concordando com a psicodinâmica, e não aos perfis.

A amostra estudada trouxe algumas limitações à pesquisa. Ocorreu a concentração dos respondentes: na categoria dos bancários $(60 \%)$, no setor de serviços $(92 \%)$ e no tipo de instituição, $62 \%$ estatal. Além disso ocorreu a limitação geográfica, uma vez que $82 \%$ dos respondentes declararam residir no DF. Outra limitação é o tamanho da amostra, relativamente pequena, para as pretensões de estudos sobre a população de trabalhadores.

Para trabalhos futuros pode-se pensar em (i) aumentar o tamanho da amostra, o que possibilitará maior aprofundamento dos resultados, (ii) abranger uma maior região geográfica e (iii) pesquisar a influência dos dados sócio-demográficos sobre as vivências de sofrimento, considerando-se realidades diferentes como trabalhadores de regiões com diferentes graus de desenvolvimento econômico e (iv) incluir mais uma variável no estudo, os valores humanos, para buscar possíveis relações entre os valores, os indicadores de prazer-sofrimento e os perfis sócio-demográficos. 


\section{REFERÊNCIAS}

ANTLOGA, Carla Sabrina; MENDES, Ana Magnólia. Sofrimento e adoecimento dos vendedores de uma empresa de material de construção. Psicologia: Teoria e Pesquisa, Brasília, v. 25, n. 2, p. 255-262, abr. /Jun. 2009 . Disponível em: <http:// www.scielo.br/scielo.php?script=sci_arttex\&pid=S0102-

37722009000200014\&Ing=en\&nrm=iso>. Acesso em: 25 Março 2010.

ASSIS, Daniela Tavares Ferreira de; MACEDO, Kátia B. Psicodinâmica do trabalho dos músicos de uma banda de blues. Psicologia \& Sociedade, Porto Alegre, v. 20, n. 1, p.117-124, abr. 2008 . Disponível em <http://www.scielo.br/scielo.php? script=sci_arttext\&pid=S0102-71822008000100013\&lng=pt\&nrm=iso>. Acessos em: 11 dezembro 2010.

DEJOURS, Chistophe. A loucura do trabalho: estudo de psicopatologia do trabalho. Tradução de Ana Isabel Paraguay, Lúcia Leal Ferreira. 5. ed. São Paulo: Cortez - Oboré, 1992. 168 p.

DEJOURS, Christophe. Subjetividade, trabalho e ação. Produção, São Paulo, v. 14, n. 3, p. 27-34, dez. 2004. Disponível em: <http://www.scielo.br/scielo.php? script=sci_arttext\&pid=S0103-65132004000300004\&lng=pt\&nrm=iso>. Acessos em: 12 dezembro 2010.

FERREIRA, Mário César; MENDES, Ana Magnólia. "Só de pensar em vir trabalhar, já fico de mau humor": atividade de atendimento ao público e prazer-sofrimento no trabalho. Estudos de psicologia (Natal), Natal, v. 6, n. 1, p. 93-104, jan./Jun. 2001. Disponivel em: <http://www.scielo.br/scielo.php?script=sci_arttext\&pid=S1413294X2001000100010\&lng=en\&nrm=iso>. Acesso em: 25 Março 2010.

HALLACK, Fernanda Sansão; SILVA, Claúdia Osório da. A reclamação nas organizações do trabalho: estratégia defensiva e evocação do sofrimento. Psicologia \& Sociedade, Porto Alegre, v. 17, n. 3, dezembro 2005. Disponível em: $<$ http://www.scielo.br/scielo.php?script=sci_arttext\&pid=S0102-

71822005000300011\&lng=pt\&nrm=iso>. Acessos em: 12 dezembro 2010.

MENDES, Ana Magnólia. Valores e vivências de prazer-sofrimento no contexto organizacional. $306 \mathrm{f}$. Tese (Doutorado em psicologia) - Instituto de Psicologia, Universidade de Brasília. 1999. 
MENDONCA, Helenides; MENDES, Ana Magnólia. Experiências de injustiça, sofrimento e retaliação no contexto de uma organização pública do Estado de Goiás. Estudos de psicologia, Maringá, v. 10, n. 3, p. 489-498, set./dez. 2005. Disponível em: $\quad<$ http://www.scielo.br/scielo.php?script=sci_arttext\&pid=S141373722005000300017\&lng=en\&nrm=iso>. Acesso em: 25 Março 2010.

MERLO, Álvaro Roberto Crespo; LAPIS, Naira Lima. A saúde e os processos de trabalho no capitalismo: reflexões na interface da psicodinâmica do trabalho e da sociologia do trabalho. Psicologia \& Sociedade, Porto Alegre, v. 19, n. 1, Apr. 2007. Disponível em <http://www.scielo.br/scielo.php?script=sci_arttext\&pid=S010271822007000100009\&lng=en\&nrm=iso>. Acesso em 11 Dezembro 2010.

PASCHOAL, Tatiane; TAMAYO, Álvaro. Validação da escala de estresse no trabalho. Estudos de psicologia (Natal), Natal, v. 9, n. 1, p.45-52, jan./abr. 2004. Disponível em: <http://www.scielo.br/scielo.php?script=sci_arttext\&pid=S1413294X2004000100006\&lng=en\&nrm=iso>. Acesso em : 24 junho 2010.

RESENDE, Sônia. Valores individuais de prazer e sofrimento em bancários de instituições financeiras públicas e privadas. $130 \mathrm{f}$. Dissertação (Mestrado em Psicologia) - Instituto de Psicologia, Universidade de Brasília. 2003. Disponível em: $<$ http:// www. journal. ufsc.br/index.php/rport/article/viewArticle/7551 >. Acesso em: 20 junho 2010.

SANTOS, Marcelo Augusto Finazzi; SIQUEIRA, Marcus Vinícius Soares; MENDES, Ana Magnólia. Tentativas de suicídio de bancários no contexto das reestruturações produtivas. Revista administração contemporânea, Curitiba, v. 14, n. 5, p. 925938, out. 2010 . Disponível em: <http://www.scielo.br/scielo.php? script=sci_arttext\&pid=S1415-65552010000500010\&lng=pt\&nrm=iso>. Acessos em: 10 dez. 2010.

SIQUEIRA, Mirlene Maria Matias; PADOVAM, Valquiria Aparecida Rossi. Bases Teóricas de Bem-Estar Psicológico e Bem-Estar no Trabalho. Psicologia: teoria e pesquisa, São Paulo, v.24, n. 2, p. 201-209, abr./jun. 2008. Disponível em: <http:// www. Scielo.br/scielo.php?=S0102-37722008000200010\&script=sci_arttext $>$. Acesso em: 25 março 2010.

STEVENSON, William j. Estatística aplicada à administração. São Paulo: Harper \& Row do Brasil, 1981. 
Apêndice A - Instruções para aplicação do questionário

\section{Pesquisa sobre o trabalho}

Olá!

Sou aluna do curso de Graduação em Administração a Distância da Universidade de Brasília, e estou aplicando o presente questionário com a finalidade de compreender melhor o trabalhador em seu dia a dia no contexto do trabalho. Este estudo representa o desenvolvimento de um projeto de pesquisa sobre $\underline{\text { Clima }}$ Organizacional e Bem-estar no trabalho, e tem por finalidade dar subsídios técnicos à minha monografia de conclusão de curso.

Sinta-se inteiramente à vontade para dar suas opiniões: não há respostas certas ou erradas, o que importa é sua opinião sincera. Suas respostas serão anônimas e mantidas em sigilo.

Obrigada por sua colaboração!! 
Apêndice B - Questionário sobre perfil sócio-demográfico.

\section{Ficha sócio-demográfica}

1) Sexo

_ feminino masculino

2) Idade entre 18 e 30 anos entre 31 e 40 anos entre 41 e 50 anos de 51 anos em diante

3) Escolaridade nível básico nível médio nível superior completo pós-graduação

4) Estado civil

__ separado / divorciado
casado / união estável viúvo

5) Nacionalidade?

6) Naturalidade?

7) Reside em que estado do Brasil?

8) Tempo de trabalho até 5 anos de 6 a 10 anos de 11 a 20 anos de 21 a 30 anos mais de 31 anos 
9) Trabalha na sua área de formação?

Sim Não

10) Sobre a instituição em que trabalha:

Caracterização:

Organização pública

Empresa privada

Empresa pública direito privado/Economia mista/Estatal

Setor de atuação:

Serviços

Indústria

Agrícola/pecuário

11) Renda

até 03 salários mínimos

de 03 até 05 salários mínimos

de 05 até 08 salários mínimos

superior a 08 salários mínimos

12) Possui dependentes

Nenhum

até 03 dependentes

de 04 a 05 dependentes

mais de 05 dependentes

13) Quem é o principal responsável pelo sustento da sua família? você seus pais / outros familiares seu cônjuge outros 


\section{Anexo A - Questionário sobre indicadores de prazer e sofrimento no trabalho}

\section{INSTRUÇÕES}

Neste questionário você deve perguntar a si próprio: "Que valores são importantes PARA MIM, como princípios orientadores em MINHA VIDA?" Sua tarefa é avaliar quão importante cada valor é para você, usando a escala de avaliação abaixo. Tente diferenciar, tanto quanto possível, os valores entre si, usando para isso todos os números.

COMO PRINCÍPIO ORIENTADOR EM MINHA VIDA, esse valor é:

Não importante

0

1

1

\section{Muito importante}

6

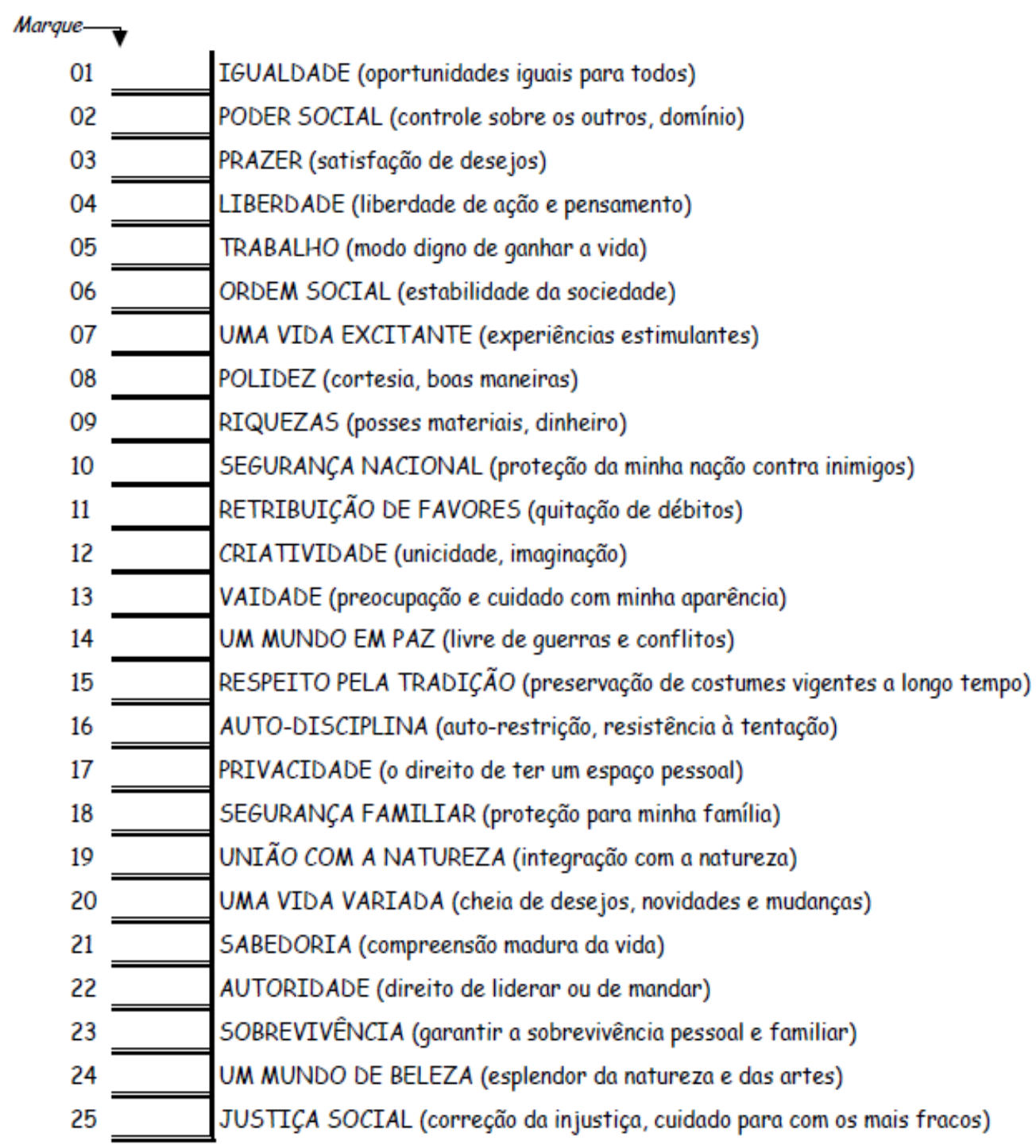

* Dentre os valores acima, o de suprema importância para mim é e o que é oposto a todos é 


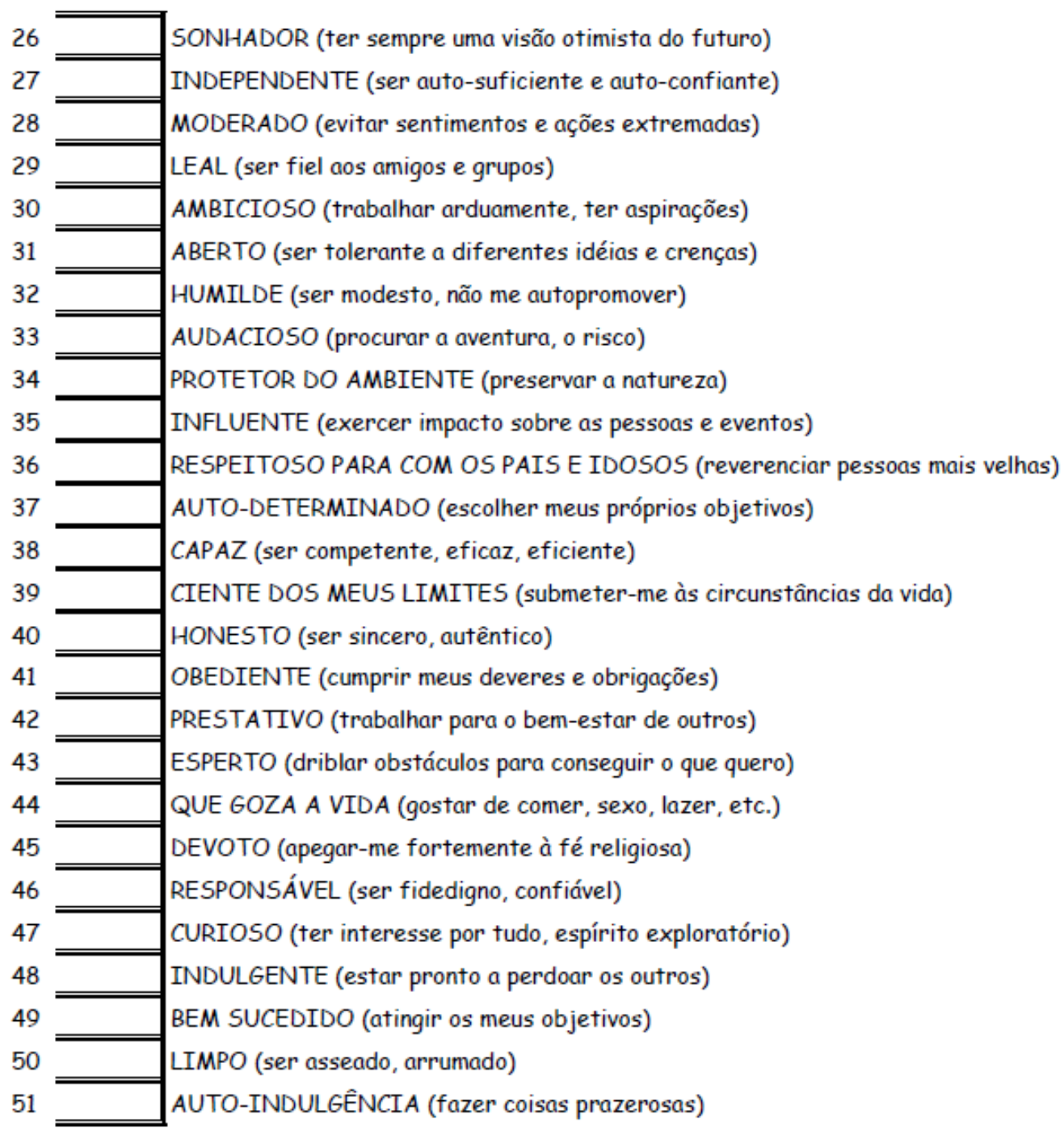

* Dentre os valores desta $2^{a}$ lista, o de suprema importância para mim é e o que é oposto é

Leia as frases que seguem, analisando cada uma de acordo com o que você sente no dia-a-dia do trabalho. Marque, utilizando a escala abaixo, o número que melhor corresponde a sua avaliação.

\begin{tabular}{|c|c|c|c|c|}
\hline 1 & 2 & 3 & 4 & 5 \\
Nunca & Raramente & Às vezes & Freqüentemente & Sempre \\
\hline
\end{tabular}

\begin{tabular}{|c|c|c|c|c|c|}
\hline 1. Sinto satisfação em executar minhas tarefas. & 1 & 2 & 3 & 4 & 5 \\
\hline 2. Quando executo minhas tarefas, realizo-me profissionalmente. & 1 & 2 & 3 & 4 & 5 \\
\hline 3. Sinto-me identificado com as tarefas que realizo. & 1 & 2 & 3 & 4 & 5 \\
\hline 4. Sinto disposição mental para realizar minhas tarefas. & 1 & 2 & 3 & 4 & 5 \\
\hline 5. Tenho liberdade para dizer o que penso sobre meu trabalho. & 1 & 2 & 3 & 4 & 5 \\
\hline 6. Tenho espaço para discutir com os colegas as dificuldades com o trabalho. & 1 & 2 & 3 & 4 & 5 \\
\hline 7. Tenho liberdade para organizar meu trabalho da forma que quero. & 1 & 2 & 3 & 4 & 5 \\
\hline 8. No meu trabalho posso usar o meu estilo pessoal. & 1 & 2 & 3 & 4 & 5 \\
\hline
\end{tabular}




\begin{tabular}{|c|c|c|c|c|c|}
\hline 9. Tenho receio de ser demitido ao cometer erros. & 1 & 2 & 3 & 4 & 5 \\
\hline 10. Sinto-me inseguro diante da ameaça de perder meu emprego. & 1 & 2 & 3 & 4 & 5 \\
\hline $\begin{array}{l}\text { 11. Sinto-me inseguro quando não correspondo às expectativas da empresa em } \\
\text { relação ao meu trabalho. }\end{array}$ & 1 & 2 & 3 & 4 & 5 \\
\hline 12. Sinto-me pressionado no meu trabalho. & 1 & 2 & 3 & 4 & 5 \\
\hline 13. Meu trabalho é desgastante. & 1 & 2 & 3 & 4 & 5 \\
\hline 14. Sinto-me sobrecarregado no meu trabalho. & 1 & 2 & 3 & 4 & 5 \\
\hline 15. Meu trabalho é cansativo. & 1 & 2 & 3 & 4 & 5 \\
\hline 16. Sinto desânimo no trabalho. & 1 & 2 & 3 & 4 & 5 \\
\hline 17. Meu trabalho é gratificante. & 1 & 2 & 3 & 4 & 5 \\
\hline 18. Sinto orgulho do trabalho que realizo. & 1 & 2 & 3 & 4 & 5 \\
\hline 19. Meu trabalho é compativel com as minhas aspirações profissionais. & 1 & 2 & 3 & 4 & 5 \\
\hline 20. O tipo de trabalho que faço é admirado pelos outros. & 1 & 2 & 3 & 4 & 5 \\
\hline 21. Sinto o reconhecimento da minha chefia pelo trabalho que realizo. & 1 & 2 & 3 & 4 & 5 \\
\hline 22. Sinto-me reconhecido pelos colegas pelo trabalho que realizo. & 1 & 2 & 3 & 4 & 5 \\
\hline 23. Sinto meus colegas solidários comigo. & 1 & 2 & 3 & 4 & 5 \\
\hline 24. Sinto-me ameaçado de demissão. & 1 & 2 & 3 & 4 & 5 \\
\hline 25. Sinto-me inseguro quando não atendo ao ritmo imposto pela minha empresa. & 1 & 2 & 3 & 4 & 5 \\
\hline $\begin{array}{l}\text { 26. Receio não ser capaz de executar minhas tarefas no prazo estipulado pela } \\
\text { minha empresa. }\end{array}$ & 1 & 2 & 3 & 4 & 5 \\
\hline 27. Meu trabalho me causa estresse. & 1 & 2 & 3 & 4 & 5 \\
\hline 28. Meu trabalho me causa tensão emocional. & 1 & 2 & 3 & 4 & 5 \\
\hline 29. Meu trabalho me causa ansiedade. & 1 & 2 & 3 & 4 & 5 \\
\hline 30. Sinto frustração no meu trabalho. & 1 & 2 & 3 & 4 & 5 \\
\hline
\end{tabular}

Fonte: Resende (2003,p.144) 